\title{
LEUCOEDEMA EM FUMANTES DE MACONHA (CANNABIS SATIVA-LIN.)
}

\author{
Hardy Ebling \\ Professor Titular de Patologia Geral \\ e Bucodental do Departamento 2

\section{Waldir Nesi} \\ Professor Assistente da Faculdade de \\ Odontologia da Universidade Fede- \\ ral Fluminense
}

\section{Edgar M. Wagner}

Professor Assistente da Feculdade de Medicina da U.F.R.G.S.

\section{SINOPSE}

Estudo clínico e histológico da mucosa bucal de 29 fumantes habituais de maconha e que tinham, na mucosa oral, manchas persistentes e esbranquiçadas. Em 27 as manchas eram de leucoedema, como foi demonstrado histològicamente.

Estudou-se clínica e histológicamente a mucosa oral de 29 fumantes de maconha, encarcerados em penitenciárias do Rio de Janeiro. Todos eram de raça negra, com idade de 18 a 38 anos e o hábito de fumar maconha variava de 6 a 21 anos.

Para exame microscópico foi obtido material observando-se os cuidados preconizados por Sanstaed e
Lowe (5), da face interna da bochecha, zona mais representativa. 0 material foi processado e corado por H.E., P.A.S., e Van Gieson.

\section{RESULTADO E DISCUSSÃO:}

O exame histológico mostrou que das 29 lesões, 27 eram de leucoedema e 2 de hiperceratose. $O$ quadro de leucoedema pode ser resumido, sob o ponto-de-vista histológico; acentuado edema intracelular nas células epiteliais das camadas superficiais (figs. 1,2 e 4 ) irregularidades na superfície do epitélio (fig. 2) paraceratose (figs. $1,2,3$ e 4) e células epiteliais superficiais «em 
espongiose,e P.A.S. negativas (fig. 3), fato já descrito (2).

A distribuição das lesões, em todos os casos, foi na bochecha, face interna, bilateral, diferindo portanto dos achados de Hammer e Villegas (2), os quais verificaram ser unilateral, do lado onde os indígenas deixavam repousando as fôlhas de coca trituradas. Pot outro lado a localização por nós descrita concorda com os achados de Pindborg, Barmes e Reed-Petersen (4), Pindborg (3), Sanstaed e Lowe (5), Archard Carlson e Stanley (1).

\section{RESUMO :}

Estudou-se clínica e histològicamente lesões esbranquiçadas persistentes da mucosa oral de detentos fumadores habituais de maconha. Sua idade variava de 18 a 38 , e a duração do hábito, variava de 6 a 21 anos. Das 29 lesões, histològicamente comprovou-se que 27 eram leucoedema e 2 de hiperceratose.

\section{LEUCODEMA IN MARIJUANA SMOKERS (CANNABIS SATIVA-IIN)}

\section{SYNOPSIS}

The authors have studied clinical and histologyaally the oral mucosa membranes of 29 marijuana smokers, actually under arrest in Rio de Ja- neiro, Brazil. The results are discurssed and related to those of other authors.

\section{RESULTDS AND DISCUSSION}

All smokers studied here are black' under arrest in several establisments in Rio de Janeiro, Brazil, and had been using marijuana regulary. Their ages are between 18 and 38 years and all got the habit between 12 and 17.

The material for microscopic examination was obtained from the inner surface of the check, having been observed the proper cares (5) and the histologycal preparations processed and stained by H.E., P.A.S., and van Gieson.

The histologycal examination showed that, from the 29 cases, 27 presented leucoedema, and 2 hyperkeratosis.

Leucoedema is characterized by the presence of marked intercellular oedema in the superficial layers, superficial irregularities, parakeratosis and superficial cells presenting espongiose and P.A.S. negative (2).

In all the cases, the lesions were observed bilaterally, differently of the results of Hamner and Villegas (2). These authors have found unilateral lesions, being this the side were natives kept the mashed coca leaves, while the bilateral lesions, in our cases, agrees with the findings of other authors $(2,3,4,5)$. 


\section{REFERENCIAS BIBLIOGRÂFICAS}

1. ARCHARD, $H$. et alii. Leukoedema of the human oral mucosa. Oral Surgery, St. Louis, 25:717-28, 1968.

2. HAMNER, J. E. \& VILLEGAS, O. L. The effect of coca leaf chewing on the bucal mucosa of Aymara and Que chua Indians in Bolivia. Oral Surgery, St. Louis, 28:287-95, 1969.

3. PINDBORG, J. J. Atlas de enfermedades de la mucusa oral. Barcelona, Salvat, 1968. p. 112.

4. PINDBORG, J. J. et alii. Epidemiology and histology of oral leucoedema among pauans and New Guineans. Cancer. Philadelphia, $22: 379-84,1968$.

5. SANDSTEAD, H. R. \& LOEWE, J. W. Leucoedema and keratosis in relation to leukoplasia of the buccal mucosa in man. Journal of the National Cancer Institute, Washington, 14:423-37, 1953.

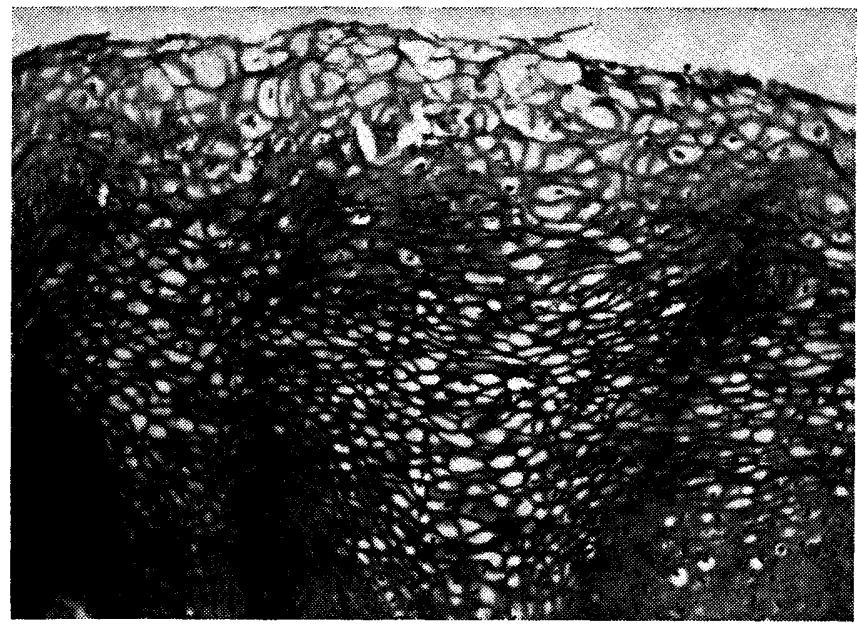

FIG. 1 - Leucoedema. Espongiose tipo «tela de galinheiro». Mucosa bucal de fumante de maconha há 17 anos. 


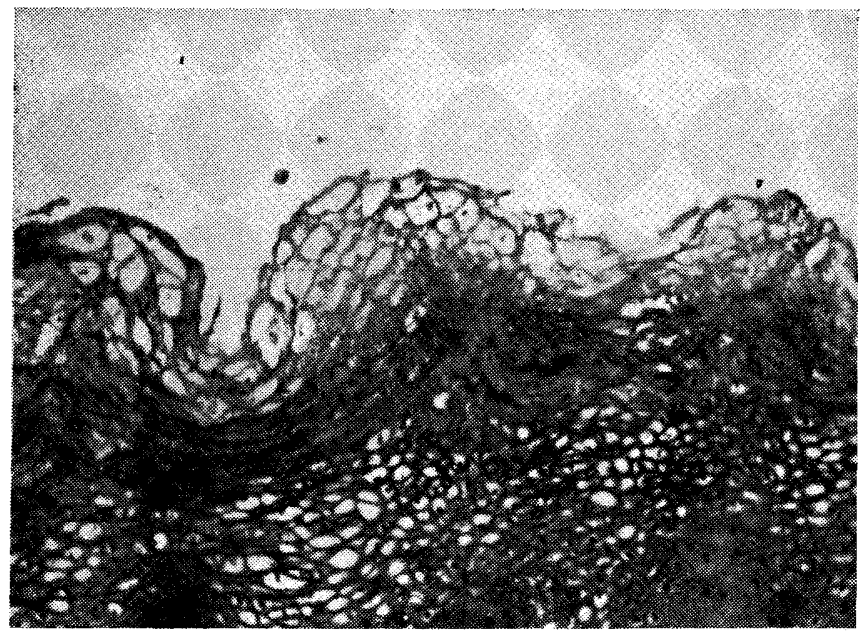

FIG. 2 - Epitélio com aspecto de «tela de galinheiro» por acentuado edema. Notar a superfície irregular. Material do mesmo paciente da fig. 1 .

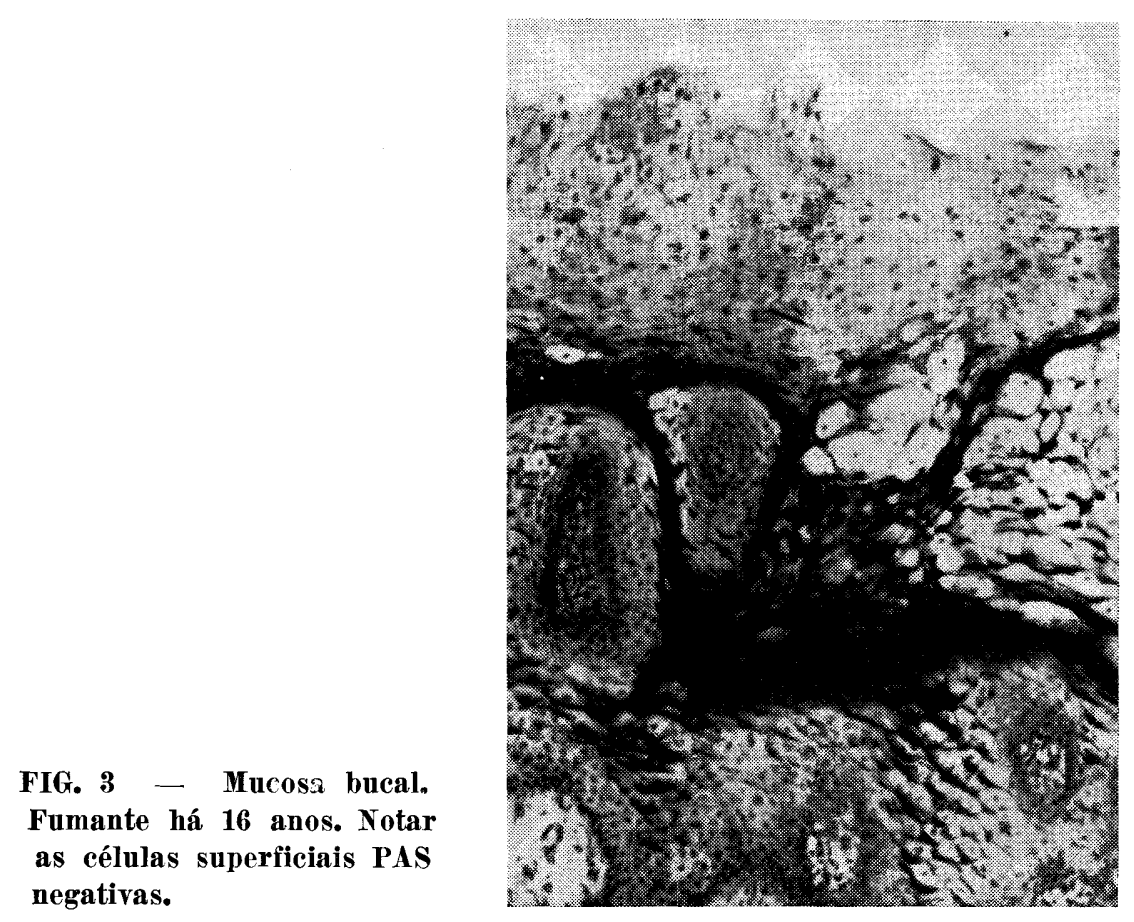

R. Fac. Odont. P. A.

$10 / 11: 35.39, \quad 1968 / 1969$ 


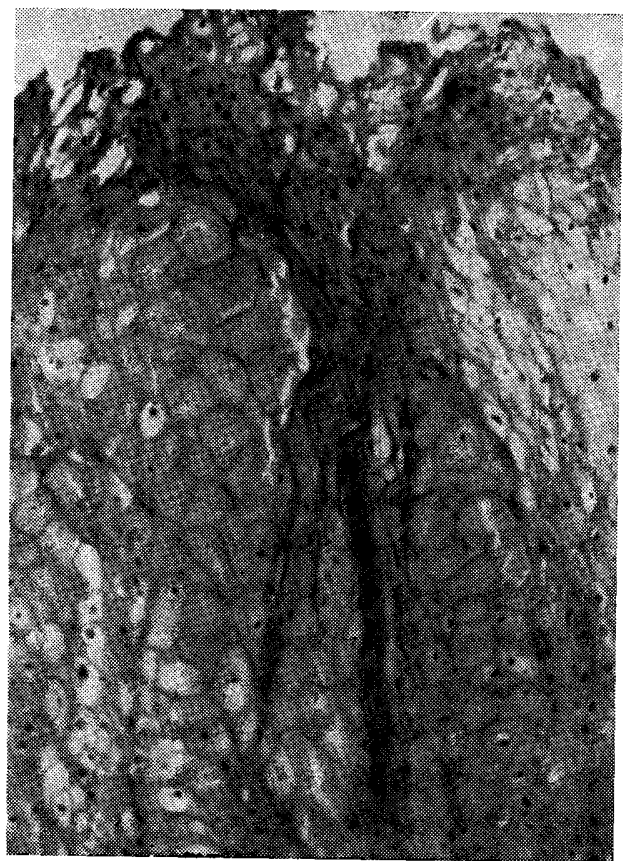

FIG. 4 - Mucosa bucal. Fumante há 9 anos. Células grandes e claras. Notar na superfície células paraceratósicas. 